\title{
Aktuálne podoby literárnej tvorivosti autorov s rôznorodou väzbou na békešskočabiansky región
}

Patrik Šenkár (Komárno)

\begin{abstract}
Abstrakt
Príspevok poukazuje na literárnu svojbytnost’ slovenskej menšiny v Mad’arsku. Stručne charakterizuje peripetie jej literárneho vývinu od konca druhej svetovej vojny až po absolútnu súčasnost’ $z$ aspektu jednotlivých publikovaných antológií. $V$ príspevku sa so špecifickým zretel'om analyzuje najnovšia (až 340-stranová) literárna antológia s názvom Naša Dolná zem (2017). Ako metodologické východisko uvádza základné súradnice časopriestoru, ktoré následne objektívno-subjektívnou formou aplikuje a konkretizuje v jednotlivých prístupoch interpretačného procesu. Kardinálnou častou príspevku je tak interpretácia jednotlivých parciálnych textov danej antológie z aspektu regionálneho aspektu a regionálneho princípu s prízvukovaním najmä minulých, ale aj prítomných atribútov, zvláštností i špecifík tejto časti Dolnej zeme, ktoré sa priamo či nepriamo objavujú v jednotlivých textoch.
\end{abstract}

\section{Kl'účové slová}

región Dolnej zeme; národnostná menšina; Slováci v Mad’arsku; literárna antológia; interpretácia

\section{Abstract \\ Current Forms of Literary Creativity of Authors with a Heterogeneous Bond to the Region of Békešská Čaba}

The paper examines the literary self-sufficiency of the Slovak minority in Hungary. It briefly characterizes the peripetiation of its literary development from the end of the Second World War to the absolute present from the aspect of various published anthologies. The paper focuses on the most recent (up to 340-page long) literary anthology called Our Lowland (2017). As a methodological basis, the basic coordinates of space-time, which in an objective-subjective form is applied and specified in the various approaches of the interpretation process. The cardinal part of the contribution is thus the interpretation of the individual partial texts of the given anthology from a regional aspect and the aspect of a regional principle, with the emphasis of the past but also the present attributes, peculiarities and specifics of this part of the Lowland that appear directly or indirectly in individual texts.

\section{Key words}

the region of Lowland; national minority; Slovaks in Hungary; literary anthology; interpretation 
„Už roky / za ruky nás drži vedome. / Nádeje delí svedomie. / A my túžbami opojeni / z dialavy do dial'avy / ideme, ideme / po tej jednosmernej ceste, / pokým len žijeme. "

(Juraj Antal Dolnozemský)

Slovenské písomníctvo na území dnešného Mad’arska má dlhoročnú tradíciu. V dnešnom zmysle slova progresívne sa však začala vyvíjat’ až v druhej polovici 20. storočia. ${ }^{2}$ Najprv to boli antológie, ktoré dláždili cestu nel’ahkým transformáciám a konkretizáciám autorských úsilí literárne tvorivých l’udí. Prvá „beletristická“ antológia Slovákov v Mad’arsku, ktorá, prirodzene, obsahovala žiaduce dobové atribúty, vyšla v roku 1955 s názvom Hrušky mamovky Špiakovej (pomenovaná podla úvodnej, rovnomennej baladickej básni-častušky Pavla Samuela). Napriek priaznivému ohlasu však zostala na dlhé roky len ojedinelým svedectvom. V klasickom zmysle slova „moderná“ antológia, ktorá bola znakom určitého obnovenia kontinuity, bola publikovaná až o viac než dvadsat rokov s príznačným názvom Výhonky (1978). Prispievatelia tejto publikácie (M. Hrivnák, P. Kondač, A. Kormoš, J. Marik, G. Papuček) sa pokúsili urobit prvé kroky k vytvoreniu „moderného“ literárneho života Slovákov v Mad’arsku. Bol to vlastne „prvý vážnejši prejav našich básnikov a novelistov pred verejnostou slovenskej národnosti na územi Mad’arska“. ${ }^{3}$ Vydanie tejto antológie bolo teda „medznikom na ceste $k$ vytvoreniu samostatného slovenského kultúrneho a literárneho života na územi Mad’arska“. ${ }^{4}$ Zaradení autori boli vlastne iniciátormi novej etapy slovenskej literárnej tvorby v Mad’arsku, združení najmä okolo redakcie Ĺudových novín. (Akýmsi „hnacím motorom“ bol Michal Hrivnák.) Pochopitel’ne, v jednotlivých textoch dominovala tematika menšinového prostredia. V roku 1980 (s miernym oneskorením k Medzinárodnému roku dietata, ktorý vyhlásila OSN, 1979) vyšla antológia s básňami pre deti s názvom Fialôcka, fiala. Intencionálne zamerané texty v nej publikovali I. Fuhl, G. Kara, A. Kormoš, J. Marik, G. Papuček, J. Szabó. Vd’aka tejto antológii sa „znova vraciame do nádherného sveta detstva“. ${ }^{5} \mathrm{~V}$ roku 1982 vyšli Pramene, ktoré obsahovali ukážky z literárnej tvorby viacerých prozaikov: Z. Bárkányi Valkán, I. Fuhl, M. Hrivnák, P. Kondač, J. Marik, A. Medvegy. Antológia čitatel'ov „informuje o tom radostnom fakte, že v Mad’arsku sa nájdu taki autori slovenskej umeleckej prózy, tvorba ktorých stoji za to, aby vyšla v tlači [...]“. ${ }^{6}$ V roku 1984 uzrel svetlo sveta zborník s názvom Chodniky, ktorý podáva čitatel’om už vyspelejšiu poéziu (až 120 básní). Publikovali v nej J. Dolnozemský, M. Fazekašo-

1 DOLNOZEMSKÝ, Juraj Antal: Manželke. In: LONOVIČOVÁ, Zuzana (ed.): Naša Dolná zem. Antológia južnodolnozemských slovenských autorov a autorov so slovenskými väzbami. Békešská Čaba - Békéscsaba: Župná knižnica v Békešskej Čabe - Békés Megyei Könyvtár, 2017, s. 53.

2 O národnostných menšinách všeobecne - a pritom aj špeciálne - v danom priestore bližšie pozri DEMUS, László: National minorities in Hungary and in east-central Europe. New Hungarian Quarterly 28, 1987, č. 106, s. $125-130$.

3 SZIKLAY, László: Úvod. In: HRIVNÁK, Michal (ed.): Výhonky. Budapešt: Vydavatel’stvo učebníc, 1978, s. 5 .

4 Tamže, s. 6.

5 ČIŽMÁRIK, Rudolf: Slovo na cestu. In: PAULÍKOVÁ, Etelka (ed.): Fialôčka, fiala. Budapešt: Vydavatel'stvo učebníc, 1980, s. 5.

6 SZIKLAY, László: Úvod. In: PAULÍKOVÁ, Etela (ed.): Pramene. Budapešt: Vydavatel'stvo učebníc, 1982 , s. 6 . 
vá, I. Fuhl, V. Halušková, G. Hanigovský, O. Kníchal, A. Kormoš, G. Papuček, P. Samuel, J. Szabó. Vydaním tejto antológie v súdobom Mad’arsku v rámci slovenskej literatúry nastalo „oživenie nášho kultúrneho pohybu, zvýšený záujem o hodnoty národnostných menšín a zosilnenie procesu možnosti sebarealizácie človeka, jedinca, v rámci kolektívu, s čím sa stretávame v rôznych sférach kultúrneho a spoločenského života [...]“.7 Aj z toho dôvodu je signifikantné, že predmetná publikácia v roku 1985 získala cenu kvality Vydavatel'stva učebníc. Odvtedy markantnejšie vychádzali samostatné zbierky básní, krátkych próz i romány Slovákov v Mad’arsku, pre ktoré ale duchovnú základňu tvorili spomínané antológie. Týmto činom sa tamojšia slovenská literatúra zapájala do čoraz širších kontextov. Potom však opät nastalo dvanásṫročné vákuum; nasledujúca antológia s názvom Cestou $k$ slovám vyšla až v roku 1996. Podla slov jej editora priniesla ,jednak portréty našich autorov, jednak ukážky z ich tvorivej dielne. Chceme tým prispiet’ k lepšiemu poznaniu tunajšej slovenskej literatúry v radoch menšinovej pospolitosti $i$ verejnosti vä̌čsinového národa“ ${ }^{8}$ Symbolicky opät po dvanástich rokoch, teda v roku 2008, vyšla zaujímavá, ba v určitom zmysle slova „priekopnícka“ kniha s názvom Pod Pilísom - tam je náš svet (2008). Bola vlastne prvá svojho druhu v Mad’arsku, ved' výberovo predstavila autorov, ktorých „spája zemepisné územie, z ktorého pochádzajú, kde žili alebo žijú aj v súčasnosti. Je to ich prekrásny pilišsky kraj“. ${ }^{9}$ Publikovali v nej J. Badura, J. Bajtek, Z. Bárkányi Valkán, Š. Bend’úr, A. Drevenka, E. Fábiánová, R. Fraňo, I. Fuhl, I. Fúziková, M. Glücková Demjénová, G. Kara, L. Klaus, A. Kormoš, G. Papuček, K. Papuček, Z. Papuček. Títo autori, pochopitel’ne, uchovávajú slovenské zvyky a tradície pilíšskeho regiónu (aj) vo svojej tvorbe. Tento edičný čin vlastne nepriamo oživil tradíciu vydávania antológií, čoho svedectvom je aj najnovšia publikácia: tentoraz z druhého konca Mad’arska, z békešskočabianskeho regiónu, teda zo Slovákmi obývaného územia.

Práve Békešská župa v Mad’arsku je krajom, v ktorom žijú Slováci v relatívne hojnom množstve. Už tri storočia od osídlenia tohto dolnozemského územia sú integrálnou súčastou makro- i mikroregiónu s osobitými kultúrnymi hodnotami a priam artefaktmi, ktoré dokazujú životaschopnost̉ a tvorivú existenciu tejto národnosti - aj na literárnom poli. V určitom zmysle slova pokračovaním tejto „literárnej“ tradície je antológia s názvom Naša Dolná zem, do ktorej sú zaradené diela, ktoré sa zrodili najmä v Békešskej župe. Sú v nej aj autori, ktorí žijú mimo tohto regiónu, avšak majú voči nemu pretrvávajúci vrúcny vztah. Sú to básnici i prozaici s viacerými zbierkami, ale aj „veršovníci“ a spisovatelia - amatéri -, ktorí svoju tvorbu chápu ako akúsi zálubu. Píšu lúbostnú lyriku, básne s motívmi každodennej práce a tradícií, slovenskej identity či reflexívne texty ako konkretizácie na vyjadrenie autorských myšlienok, večných právd a ponaučení. Je to reprezentatívny prehlad o autoroch a ich dielach, spätých so slovenskou kultúrou v rámci juhovýchodnej časti Dolnej zeme. Antológia s pestrou žánrovou paletou podáva obraz

7 DIVIČANOVÁ, Anna: Úvod. In: RYBOVÁ, Etelka (ed.): Chodníky. Budapest:: Vydavatel’stvo učebníc, 1984, s. 5.

8 KNÍCHAL, Oldřich: Odkial ideme a kam smerujeme. In: KNÍCHAL, Oldřich (ed.): Cestou k slovám. Budapešt: Združenie slovenských spisovatelov a umelcov v Madarsku, 1996, s. 9.

9 PAPUČEK, Gregor - BÁRKÁNYI VALKÁN, Zoltán: Vitajte u nás! In: PAPUČEK, Gregor - BÁRKÁNYI VALKÁN, Zoltán (eds.): Pod Pilišom - tam je náš svet. Literárna antológia pilišskych slovenských autorov. Mlynky: Spoločnost Fuhl Bt, 2008, s. 4. 
symbolicky pestrej tváre tohto regiónu pomocou diel, prostredníctvom ktorých možno spoznat krásy a zvláštnosti slovenského jazyka, miestnu históriu Slovákov a ich zvyky, typické miesta, svojráznost krajiny a podobne. V jednotlivých textoch je identifikovatelná úzka citová väzba autorov $\mathrm{k}$ tomuto kraju. Je preto východiskom pri umeleckom stvárňovaní ich autorských zámerov v pozadí akéhosi pocitu spolupatričnosti. Ponúka najaktuálnejšiu tvorbu vybraných autorov; výnimku tvoria iba zosnulí. Tento edičný čin nanovo vykresluje zaužívaný obraz tejto časti Dolnej zeme. Svojou dvojjazyčnostou rozširuje okruh autorov a potvrdzuje úsilie o zachovanie aj menej známych písomných, lokálnych hodnôt. Sú to najmä slovenské tradície tejto oblasti. Vd’aka spomínanému bilingvizmu sa však otvára aj smerom $\mathrm{k}$ čitatelom mad’arskej národnosti. Celkovo teda tento výber svedčí o bohatosti a rozvetvenosti historických, kultúrnych, literárnych a jazykových tradícií okolia. Má však dôležitú literárnu hodnotu aj pre nasledujúce generácie. Okrem toho má za úlohu symbolicky i konkrétne "poukázat na bohatost' a mnohorakost' kultúry a literatúry južnodolnozemského regiónu, ako zámer rozšírit záujem o slovenskú literatúru medzi mad’arskými čitatelmi . V tejto súvislosti antológiu Naša Dolná zem / A mi Alföldünk možno vnímat’ ako nový model, ktorý je v súčasnosti jediný svojho druhu“.${ }^{10}$ Gradovane to teda platí - totum pro parte - aj pre kultúrny kontext Slovákov v Mad’arsku. Samozrejme, kniha má na zreteli aj špecifickú, tzn. dvojakú identitu príslušníkov tejto národnosti, ktorá sa tak odzrkadluje aj v tematickom či obsahovom pláne jednotlivých textov (nehovoriac pritom o jazykových mutáciách).

V pozadí tejto myšlienky a autorského postupu sa publikácia delí na dva väššie celky: diela slovenských autorov v slovenskom a mad’arskom jazyku (19 autorov; spolu s ich životopismi) a diela autorov so slovenskými väzbami v mad’arskom jazyku (19 autorov; spolu $\mathrm{s}$ ich životopismi). Pochopitelne, celá kniha je vytvorená v pozadí akéhosi ducha dolnozemskej súčinnosti. Niekedy viac, inokedy menej: raz je to z aspektu priameho kontaktu so slovenskou kultúrou, inokedy sprostredkovane z dialky. Je to však komplexne osožné, lebo poukazuje na dôležitý segment svojbytnosti slovenského ducha za geografickými hranicami pravlasti. Je zaujímavé pritom pozorovat ako slovanské literatúry (teda aj literatúra Slovákov v Mad’arsku) v posledných desiatich rokoch vnímala a akým spôsobom riešila danú problematiku, teda „či zmierñovala staré predsudky a národné stereotypy, alebo či bola otvorená novým javom, či ich podporovala atd’. Je zrejmé, že demokratická sloboda vyjadrením vlastných názorov a prianí tiež poskytovala príležitost' vyjadrit svoje názory na národnostno-etnické otázky". ${ }^{11}$ A práve tento koncept sa explicitne (ale aj druhoplánovo) objavil aj vo viacerých autorských prístupoch a konkretizáciách v daných (analyzovaných) textoch. Symbolicky povedané: Dolná zem je - vychádzajúc z jednotlivých motívov prototextov - identifikovatelná nekonečnými žírnymi rovinami, žltými poliami po žatve a omamnou vôňou sladkého hrozna s drobnými zrnkami. Vstupnou bránou do tohto sveta je malá

10 MARUZSOVÁ ŠEBOVÁ, Katarína: K novej antológii Naša Dolná zem / A mi Alföldünk. In: LONOVIČOVÁ, Zuzana (ed.): Naša Dolná zem. Antológia južnodolnozemských slovenských autorov a autorov so slovenskými väzbami. Békešská Čaba - Békéscsaba: Župná knižnica v Békešskej Čabe - Békés Megyei Könyvtár, 2017, s. 24.

11 DABROWSKI, Mieczyslaw: The problems of national-ethnic, cultural, and sexual minorities in Slavic literatures after 1989. Neohelicon 33, 2006, č. 2, s. 85-86. 
dolnozemská stanica s príznačným oparom slivkového stromoradia. Je pritom zaujímavé a príznačné uviest', že slovenského ducha symbolizujú žlté domy s prednou verandou a hrubými múrmi či nekonečne dlhé a rovné ulice, z ktorých však materinský jazyk postupne mizne. Svet minulých dôb ešte pripomína evanjelický cintorín so slovenskými nápismi a kostol s trojjazyčnými modlitbami, prosbami a vd’akami. Morálnym imperatívom je Biblia a Tranoscius. Je to svet Jaminy (časti Békešskej Čaby), Pitvaroša i Slovenského Komlóša, kde sa tradujú legendy o bičkášoch (mladí mestskí betári s nožíkom vo vrecku) či árendášoch (prenajímatelia majetku, najmä pôdy). Bandi báčiho starý svet sa postupne mení v posledných decéniách a na Vel'kej mad’arskej nížine sa redukujú hmotné i nehmotné slovenské pamiatky. Zhromažd’uje ich - a tým zachraňuje - najmä Slovenský oblastný dom a Sálašské múzeum. Pre človeka nového milénia sú však zaujímavé aj gastronomické festivaly (ako napríklad sútaž v príprave kyslej prílohy k jedlu či klobásový festival). Nepriamo sa aj počas nich prehlbuje slovenská národ(nost)ná identita. Nie je však dobré zabúdat’ ani na zrúcané sálaše, ktoré symbolizujú zabudnuté svety.

$\mathrm{V}$ jednotlivých textoch sa kardinálne objavuje uvedomenie si determinovanosti vlastného minoritného stavu - akoby „na okraji mapy“. Konkretizuje sa prekrásna slovensko-mad’arská Békešská Čaba, v ktorej národnostné bytie stojí na pevných základoch evanjelického Tranoscia. Lyrický subjekt si tak presne identifikuje vlastný časopriestor existencie i spolužitia, tesne spätý s ovládaním (nárečovej) slovenčiny ako atribútu pretrvávania: „Čabenja zme, Slováci, s čabjanskim jazikom, / keri sa už málo zodrav, prepáčte nám za to. / Cítte sa u nás ako medzi svojimi, / Mad’ari i Slováci múrajú tu dobré mosti. "12 V pozadí týchto daností a myšlienok je však konkretizovaná aj určitá pochybovačnost’ vo vztahu Čabäna k vlasti(am). (Ktorá z nich príjme Čabänov už konečne za svojich?) Všetko vychádza z celkom podobnej až „osudovej“ trikolóry poznania, nádeje a viery. Je to vlastne poeticky zhmotnená túžba po svedomitosti a opojení v spolužití v pozadí tradícií. V zbierke je možné sledovat pritom určitú ambivalentnost', ktorá sa týka azda najdôležitejšieho atribútu dômyselnej existencie národnosti: jazyka. Na jednej strane vd’aka asimilačným procesom Slovákov v Békešskej Čabe ubúda, ved’: „Moja smutná slovenčina / Nedostane novie dažde. / Na dolnej zemi viskina, / Lista jej d’alej nerastie."13 Na druhej strane v autorskom idiolekte békešskočabianskych autorov je evidentné úsilie o budovanie jednoty a spolupatričnosti (najmä) v rámci vlastnej komunity. Aj v pozadí toho niektoré apely pre vnímavých percipientov znejú mierne archaicky: „Rodáci mili! / Chytte sa bujarého / slovenského tátoša hrivy, / aby jazyk náš / ostal $i$ na d’alšie storočia / v našom rodisku / stále živý. "14 Nimi sa vyjadrujú určité buričské myšlienky v intenciách (ne)bytia Slovákov v Mad’arsku. Akési romantizujúce myšlienky o národe, vlasti a viere sa však plnohodnotne etablujú do jednotlivých básnických výpovedí. Slovenčina sa tak stáva akýmsi zlatom, ktorú je potrebné neustále si zvelad’ovat' nielen doma, ale aj v samovzdelávacom krúžku, ved’: „Na Dolnej zemi, v Békěsskej Čabe / zrjekli sa ňiekel'ki Slováci. / Rozhodli sa o tom, že založja krúžok. / Budú sa schádzat', kde svoj

12 ZELENYÁNSZKI, Ondrej: Dom slovenskej kultúry. In: LONOVIČOVÁ, Zuzana (ed.): Naša Dolná zem. Antológia južnodolnozemských slovenských autorov a autorov so slovenskými väzbami. Békešská Čaba Békéscsaba: Župná knižnica v Békešskej Čabe - Békés Megyei Könyvtár, 2017, s. 136. 
rodni / slovenski jazik budú spolu rosprávat."15 Tieto myšlienky svedčia o akejsi kontinuite jestvovania Slovákov v uvádzanom regióne, ktorí tak nezabúdajú na kifle, tvarožniky, magáňe či reiteše. L’udová tradícia a kultúra je tak ich pevným základom na báze - už spomínanej - kontinuity: vhodený veniec do Kereša symbolizuje spätost’ minulosti, prítomnosti a budúcnosti Slovákov v Békešskej župe. Je to teda (aj v súčasnosti a v zrkadle básnických a prozaických výpovedí) priestor rodného kraja s priezračnou rovinou a úrodnými lánmi. Spája sa tak príroda s človekom, živitel'ka s tradíciou, minulost’ s budúcnostou, nakol'ko: „Na priadkach, kde znie vábny zvuk tambury, / vy v krásnom po predkoch zdedenom kroji / krútite sa veselo v objati / švárnych šuhajov svojich."

V jednotlivých textoch sa často objavuje aj akási prosba lyrického subjektu za zachovanie slovenského rodu smerom k Bohu a symbol blúdiaceho človeka počas tmavej noci. Strach o jazyk je baladicky opísaný ako kl’ukatá cesta okolo Kereša. Lyrický subjekt sníva o jednote (ako poviazané snopy); ako príklad mu slúži idealizovaná Horná zem. V opozícii my - oni poukazuje na svojbytnost́ Čívanov, Ostrihomčanov, Sarvašanov - Bratislavčanov, Gabčíkovčanov, Štúrovčanov. Pravlast’ pritom opisuje ako duševne blízku zem, ktorej srdce očakávajúco bije v dlani krajana. Storočné tradície a ich konkretizácie (napríklad v jednotlivých spevoch Tranoscia) sa symbolicky opisujú potápajúcou sa lod’ou a zmenou sálašov na pusty. Na vine je 20. storočie s pretechnizovanou dobou a bez ludskej tváre. Vtedy sa vo víre modernej doby stráca aj malý sedliak v Gerendáši, ktorý je však pamätníkom i po tridsiatich rokoch (založenie slovenského krúžku, hrejivé spomienky na kazatelov, učitelov, školy). Vyzdvihuje sa teda širšie uznanie slovenskej kultúry, ktorá sa aj napriek neduhom nových dôb úplne nevytráca. Alúzia na Dévu sa kontaminuje s nedávnym opisom víchrice $\mathrm{v}$ Tatrách, vytvárajúc tak akési duchovné spojivo. Rodná zem je drahá, úrodná: tam sa aj chmel hojne rodí. V jednotlivých textoch sa často spomína rodná vieska, ktorá dala impulz spomínaným kl’ukatým viacrozmerným cestám hladania pravdy. Človek na tejto ceste, postupne umývaný dažd’om skúseností, si však má zosúladit hladanie prítomnosti a vieru minulosti. Musí mat’ pevné a hlboké základy ako evanjelický chrám v Slovenskom Komlóši; musí identifikovat vnútornú ozvenu, strážit vlastné svedomie a poklonit sa predkom. Boli to vlastne oni, ktorí vyorali hlboké dolnozemské brázdy a hlbšie hladali pravdu Juraja Tranovského. Aj z toho dôvodu je dôležité spolužitie rôznych etník v pozadí vzájomnej úcty; aj preto sa dáva veniec do Kereša a uctieva sa tajomná sarvašská deva.

Dôležitú úlohu pritom zohráva aj samotná kompozičná výstavba textu a usporiadanie jeho jednotlivých zložiek do uceleného jazykového celku, ktorý tvorí umeleckú výpovednú hodnotu vychádzajúcu od autora a smerujúcu k potenciálnemu adresátovi (čitatel’ovi). V uvádzaných textoch je relatívne častý tzv. architektonický impulz, t. j. výrazný moment na začiatku a na konci odseku - ako príklad uved’me prózu Tibora Mótyána či Istvána Balogha. Celkovo sú najčastejšie tzv. otvorené kapitoly s lineárne plynúcim dejom, v rámci architektoniky textu sa najčastejšie využíva symetrický kompozičný prin-

ČIČEL, Michal: Tridsat' rokov. In: Tamže, s. 41.

16 HUDÁK, Štefan: Komlóšske dievčatá. In: Tamže, 2017, s. 76. 
cíp. Vychádzajúc (až) z determinujúceho chronotopu, sú to texty najmä s konštantným priestorom a chronologickým časom.

Celoplošne je dôležitá otázka identity pri zachovaní si etnickej príslušnosti a živého jazyka. Aj preto je z hladiska lyrického subjektu vel'mi tažké opustit priezračnú rovinu. V binárnej opozícii vonku - vnútri sa postupne vytvára individuálna pamät, ktorej konkretizáciou sú uvádzané texty - akoby odkazy dolnozemskej prírode. Na jednej strane sú neúnavní kosci či matka s fiertuškou (zásterou); na strane druhej uponáhlaný človek nového milénia. Spoločnou črtou by však mala byt spoločná modlitba za fyzickú i psychickú hojnost', za národ(nosti), vieru a vlast'. Vyznania sú spredmetnené najmä lubozvučnými piesňami, teda akýmsi bájnym spevohlasom pitvarošskej roviny k Hornej zemi. Na širšej ploche sa opisuje sedliacky život: práca počas paše či hra tamburášov. Slovenčina sa však postupne stáva aj v tomto chronotope zvláštnostou: spisovný jazyk sa silno kontaminuje nárečovými prvkami a objavuje sa aj národnostná asimilácia. Opisujú sa jazykové zvyky Slovákov a aké-také vplyvy polhodinového rozhlasového vysielania v slovenčine. Aj toto redukované kvantum však prináša žial jednoduchému slovenskému človeku, ktorý cíti bolest’ najmä vtedy, ked' vidí postupné hynutie toho, za čo fyzicky i psychicky pracoval po celý život. K rovine sa postupne dostáva pendant hory (Pilîs).

Lyrický subjekt (pars pro toto) je strážcom viery, svedkom piesní škovránkov a hladačom agátových listov. Jazyk prirovnáva k večne živému prameňu. Na druhej strane sa však bojí o svoju národnost', ktorú prirovnáva k zakliatej Venuši na brehu Kereša. Vyzýva, aby dolnozemskí Slováci ani symbolicky nežili na okraji nížiny (akoby na periférii). Hlása, aby smelo bojovali za svoje ludské a občianske práva. Ako vzor má pre nich byt Ondrej Áchim Likier - politik so slovenskými koreňmi, bojovník za ludské a národ(nost)né práva. Vnímavý človek teda musí mat úctu k svojim predkom, ktorí na sálaš prišli spolu so slovenčinou. Postupne sa od tej doby tradujú aj rôzne legendy či pravdivé príhody, ktoré môžu byṫ vzorom aj pre dnešné generácie. Aj z toho dôvodu sa dolnozemský človek musî racionálne prispôsobit okoliu a zachovat si slovenčinu aj na sálaši i okolo vahadlovej studne. Spomínané tradície sa musia konkretizovat aj nosením baranice, v priezvisku Husár, v obyčajoch počas Kračúna (Vianoc) i v myšlienkach apovky (otca). Je teda dôležité cítit zemskú prítažlivost̉ rodiska v pozadí zvyklostí: práca počas lámačiek, vyšívanie djoučenec (dievčat), pečenie bagáňov (pagáčov), kifli (buchiet), pitie pálenky v kančovách (krčahoch). Tak sa symbolicky stretne Tranovského hymna na puste s melódiami Bélu Bartóka. Vzdáva sa hold pilišsskym hruškám a chráni sa rodná reč aj vd’aka Otčenášu. Dôležité sú teda korene i výhonky, teda chvála Boha i Slovákov v Békešskej Čabe, Huti, Mlynkoch, Santove, Senváclave...

Postupne sa dáva do kontrastu zhon velkomesta (Starý Budín) a pokoj malomesta (Vacov). Pri nich tečie Dunaj ako nemý svedok zachovania rodu a akýsi kizbešitố (doručovatel') dobrých i zlých správ. Nad všetkými však stojí všemohúci Boh a práca, ktorá je povinnostou statočného človeka. Dôležité sú pritom stretnutia i rozlúčky s rodiskom, ktoré sú totožné s úlohou Slnka. Aj z toho dôvodu je čitatel'sky efektívny opis čabianskej zabijačky a následnej veselice v Dome slovenskej kultúry.

Symbolicky sa dáva do kontrastu voda Dunaja pri Nagymarosi a okolitá komlóšska príroda. Na príklade konkrétnej rodiny sa uvádza ekumenické spolužitie rôznych 
vierovyznaní. Prízvukuje sa dôležitost̉ orálnej histórie z aspektu osídlenia Békešskej Čaby Slovákmi z Oravy spred tristo rokov (teda presne v roku 1718). V trojuholníku Makov - Békešská Čaba - Slovenský Komlóš sa uvádza dôležitosţ „miestnej slovenčiny“, ktorá prirodzene obohacuje krajanov, ktorí pôvodne prišli z Gemera. Sú to oni, ktorým dodnes na tejto rovine chýba vrchovatý kraj predkov. Spomína sa pritom aj život starších generácií na Orave pri aktuálnom pohlade na domáce atribúty - konkretizované žltým priečelím Hotela Komló.

Dôležité sú aj spätné, empatické pohlady k predkom. Vtedy je však dolnozemské srdce smutné, pričom útechu prinášajú iba krásne slovenské ludové piesne. Tie nosia v sebe stmelujúcu silu spoločenstva pri pocite dávno zabudnutých vôní zvolenských lesov. Je to elementárna moc v melancholickom podtóne dolnozemských Slovákov, ktorí sa však občas cítia ako druhoradí občania svojej terajšej vlasti. Musia sa však aj napriek tomu vzopriet voči neduhom, podobne ako spomínaný Ondrej Áchim Likier, ktorý sa postavil v prípade potreby aj proti rendírom (žandárom) za práva utláčaných.

Dnešný dolnozemský sálaš je opustený, varianty jazyka však žijú nad’alej, takisto ako spomienky na slovenské zvyky prastarých rodičov v Sarvaši. Opisuje sa aj ich tradičné jedlo ako krv na cibuli, kifle (buchty) so slivkovým lekvárom a kapusňik (podplamenník plnený kapustou). Koniec koncov je však dôležité vzájomné porozumenie.

Významná je pritom aj prítomnost knižnice v živote sedliakov. Opis detí pri hrách i štebot, tanec, spev - je opät kontaminovaný. Slovenské sa mieša s mad’arským, a tak vytvára uvádzanú pestrost'. Slovenské izby sú farebné a mad’arské biele. Sú svedkami legiend a babských rečí počas páračiek. Sú to teda cesty slovenského slova nielen od steny k stene, ale aj od slovenského malomesta pri Kereši až po Pešt. Okolie Békešskej Čaby sa opisuje ako ideálne, špecifické a zaujímavé. Je to nezabudnutelný kraj, privolávajúci spät svojich rodákov vd’aka večnému putu. Sú to tvrdé békešské hrudy, po ktorých chodil aj samotný Sándor Petőfi. Hlas zvonov vysokých turní evanjelických kostolov a pestré návyky odievania Dolnej zeme musí vábit vnímavých ludí. Symbolicky vnímané: len vtedy sa opät zrodia jedle pri Kereši, cyprusy pri sarvašských močiaroch a tvorivé myšlienky pod oblúkmi školy Samuela Tešedíka.

Na základe vyššie spomínaných atribútov môžeme azda až s istotou uviest', že Slováci v Mad’arsku dodnes vytvárajú (aj ked’ v menšom rozsahu ako v minulosti) kultúrne - teda aj literárne - hodnoty, ktoré sú vábivé, osožné, zaujímavé. Vnímaví čitatelia tak aj vd’aka viacdimenzionálnej percepcii dostávajú objektívne i subjektívne informácie, týkajúce sa dolnozemského koloritu. Aj takýmto spôsobom si uvedomujú, že zahraniční Slováci tvoria integrálnu súčast̉ celoslovenského kultúrneho kontextu s určitými literárnymi hodnotami. V pozadí daného chronotopu sú teda mimoriadne dôležité „priestorové vztahy jazyka a literatúry s dôrazom na sociológiu a politológiu a problém disciplinarity, interdisciplinárnosti a multidisciplinarity, t. j. identifikácia discipliny v zmysle, remesla'. Je nevyhnutné vyhnút' sa módnosti areálových štúdiú, je potrebné skôr ich relativizovat', hladat ich vztahy $k$ iným disciplinam, napr. k vizualizácii, ikonosfére, teórii literárnej histórie, dialógu kultúr a kultúrnym štúdiám ako takým “ . ${ }^{17}$ A práve v súradniciach literárnej histórie a dialógu kultúr je dôležitý

17 POSPÍŠIL, Ivo: Spatiality / Area and Literature. World Literature Studies 2, 2010, č. 1, s. 61. 
komplexný (teda aj popularizačno-interpretačný) prístup k tzv. národnostnej literatúre, t. j. (v našom prípade) k literatúre Slovákov žijúcich v zahraničí. Spredmetnením toho je aj úsilie békešskočabianskych autorov na poli konkrétneho písaného slova.

\section{Literatúra}

ČIŽMÁRIK, Rudolf: Slovo na cestu. In: PAULÍKOVÁ, Etelka (ed.): Fialôčka, fiala. Budapešť: Vydavatel'stvo učebníc, 1980, s. 5-6.

DABROWSKI, Mieczyslaw: The problems of national-ethnic, cultural, and sexual minorities in Slavic literatures after 1989. Neohelicon 33, 2006, č. 2, s. 75-90.

DEMUS, László: National minorities in Hungary and in east-central Europe. New Hungarian Quarterly 28, 1987, č. 106, s. 125-130.

DIVIČANOVÁ, Anna: Úvod. In: RYBOVÁ, Etelka (ed.): Chodníky. Budapesț: Vydavatel’stvo učebníc, 1984, s. 5-7.

KNÍCHAL, Oldřich: Odkial' ideme a kam smerujeme. In: KNÍCHAL, Oldřich (ed.): Cestou k slovám. Budapešt: Združenie slovenských spisovatelov a umelcov v Mad’arsku, 1996, s. 3-9.

LONOVIČOVÁ, Zuzana (ed.): Naša Dolná zem. Antológia južnodolnozemských slovenských autorov a autorov so slovenskými väzbami. Békešská Čaba - Békéscsaba: Župná knižnica v Békešskej Čabe - Békés Megyei Könyvtár, 2017.

MARUZSOVÁ ŠEBOVÁ, Katarína: K novej antológii Naša Dolná zem / A mi Alföldünk. In: LONOVIČOVÁ, Zuzana (ed.): Naša Dolná zem. Antológia južnodolnozemských slovenských autorov a autorov so slovenskými väzbami. Békešská Čaba - Békéscsaba: Župná knižnica v Békešskej Čabe - Békés Megyei Könyvtár, 2017, s. 20-24.

PAPUČEK, Gregor - BÁRKÁNYI VALKÁN, Zoltán: Vitajte u nás! In: PAPUČEK, Gregor - BÁRKÁNYI VALKÁN, Zoltán (eds.): Pod Pilíšom - tam je náš svet. Literárna antológia pilî́šskych slovenských autorov. Mlynky: Spoločnost̉ Fuhl Bt, 2008, s. 3-4.

POSPÍŠIL, Ivo: Spatiality / Area and Literature. World Literature Studies 2, 2010, č. 1, s. 61-73.

SZIKLAY, László: Úvod. In: HRIVNÁK, Michal (ed.): Výhonky. Budapešt: Vydavatel'stvo učebníc, 1978, s. 5-12.

SZIKLAY, László: Úvod. In: PAULÍKOVÁ, Etela (ed.): Pramene. Budapešt:: Vydavatel’stvo učebníc, 1982, s. 5-8.

doc. PaedDr. Patrik Šenkár, PhD.

Katedra slovenského jazyka a literatúry

Pedagogická fakulta, Univerzita J. Selyeho

Bratislavská cesta 3322, 94501 Komárno, SK

senkarp@ujs.sk

This work can be used in accordance with the Creative Commons BY-SA 4.0 International license terms and conditions (https://creativecommons.org/licenses/by-sa/4.0/legalcode). This does not apply to works or elements (such as image or photographs) that are used in the work under a contractual license or exception or limitation to relevant rights. 
